\title{
AGRO-CLIMATIC SUITABILITY AND WATER REQUIREMENT FOR TANZANIA GUINEAGRASS CULTIVATION IN THE STATE OF CEARÁ ${ }^{1}$
}

\author{
NAILSON LIMA SANTOS LEMOS ${ }^{2 *}$, ANA CLARA RODRIGUES CAVALCANTE ${ }^{3}$, THIERES GEORGE FREIRE DA \\ SILVA ${ }^{4}$, JOSÉ RICARDO MACEDO PEZZOPANE ${ }^{5}$, PATRÍCIA MENEZES SANTOS ${ }^{5}$, MAGNO JOSÉ DUARTE \\ CÂNDIDO ${ }^{6}$
}

\begin{abstract}
This study aimed to define areas suitable, and the irrigation water requirement for, cultivation of Tanzania guineagrass in the state of Ceará, Brazil. Tanzania guineagrass yield was estimated by a mathematical model, which considers the crop actual evapotranspiration, resulting from the crop climatological water balance. The water requirement throughout the year was estimated for soils with a water holding capacity of 20 (shallow soils), 40 (sandy soils), 60 (soils with medium texture) and $100 \mathrm{~mm}$ (clay soils). The relative frequency of occurrence of monthly productions greater than $2,750 \mathrm{~kg} \mathrm{DM} \mathrm{ha}{ }^{-1} \mathrm{month}^{-1}$ was obtained for different areas in Ceará, representative of most of the state's economic mesoregions. Tanzania guineagrass annual yields in the state of Ceará were between $20,000-30,000 \mathrm{~kg} \mathrm{DM} \mathrm{ha}^{-1}$ year $^{-1}$. During the rainy season, the productive potential varies with the economic mesoregion, which presents different climatic conditions. The state of Ceará is only suitable for the rainfed production of Tanzania guineagrass for 4 months each year, predominantly from February to May, while weather conditions do not favor the development of this grass in the remaining months.
\end{abstract}

Keywords: Dry matter accumulation rate. Mathematical model. Panicum maximum. Water storage capacity.

\section{APTIDÃO AGROCLIMÁTICA E NECESSIDADE HÍDRICA PARA O CULTIVO DO CAPIM TANZÂNIA NO ESTADO DO CEARÁ}

\begin{abstract}
RESUMO - O objetivo desse trabalho foi delimitar áreas aptas e o requerimento hídrico de irrigação para cultivo do capim Tanzânia no estado do Ceará. A produtividade do capim Tanzânia foi obtida a partir de um modelo matemático que assume os valores da evapotranspiração real, resultante do balanço hídrico climatológico da cultura. A necessidade hídrica para reposição de água ao longo do ano para solos com capacidade de água disponível de 20 (solos rasos), 40 (solos arenosos), 60 (solos de textura média) e $100 \mathrm{~mm}$ (solos argilosos). A partir da TAMS obteve-se a frequência relativa de ocorrência de produtividade mensal em diferentes municípios Cearense. Os valores de produtividade do capim Tanzânia no estado do Ceará predominaram entre 20.000 e $30.000 \mathrm{~kg} \mathrm{MS} \mathrm{ha}^{-1}$ ano $^{-1}$. Durante os meses chuvosos o potencial produtivo varia em função da mesorregião econômica, as quais apresentam condições climáticas distintas. Portanto, o estado do Ceará possui aptidão para produção do capim Tanzânia, sob regime de sequeiro, durante apenas quatro meses, predominantemente, de fevereiro a maio, sendo que as condições climáticas não favorecem o desenvolvimento do capim nos demais meses.
\end{abstract}

Palavras-chave: Taxa de acúmulo de matéria seca. Modelo matemático. Panicum maximum. Capacidade de armazenamento de água.

\footnotetext{
${ }^{*}$ Corresponding author

${ }^{1}$ Received for publication in $05 / 12 / 2016$; accepted in 01/25/2017.

Paper extracted from the post-doctorate research of the first author.

${ }^{2}$ Department of Animal Science, Universidade Federal de Sergipe, Nossa Senhora da Glória, SE, Brazil; agronailson@yahoo.com.br.

${ }^{3}$ Center of Forage and Grassland, EMBRAPA Caprinos e Ovinos, Sobral, CE, Brazil; ana.clara@embrapa.br.

${ }^{4}$ Academic Unit of Serra Talhada, Universidade Federal Rural de Pernambuco, Serra Talhada, PE, Brazil; thieres_freire@yahoo.com.br.

${ }^{5}$ Center of Research and Development, EMBRAPA Pecuária Sudeste, São Carlos, SP, Brazil; jose.pezzopane@embrapa.br, patricia.santos@embrapa.br.

${ }^{6}$ Department of Animal Science, Universidade Federal do Ceará, Fortaleza, CE, Brazil; magno@ufc.br.
} 


\section{INTRODUCTION}

The Tanzania guineagrass (Panicum maximum Jacq. Tanzania) is a forage plant used in intensive animal production systems in Central-West and Southeast Brazil. According to Jank et al. (2010), this species develops well in areas with rainfall exceeding $750 \mathrm{~mm}$ year ${ }^{-1}$, with mild water deficit. It requires a moderate to clay soil texture, with medium to high fertility and no acidity problems. Its use in a semiarid environment has been suggested to increase forage production and to improve animal production systems sustainability.

Tanzania guineagrass developed well on the coast and in the north of the state of Ceará (CUTRIM JÚNIOR, et al., 2010, 2011; POMPEU et al., 2008, 2009a, 2009b; VALENTE et al., 2010) but its productive potential was not investigated in different soil or under various climatic conditions present in the state's mesoregions.

Empirical agrometeorological models may be used to estimate crop production and generate information about species suitability for cultivation in various environments. These models have been adjusted for various tropical forage species, such as Cynodon, Panicum and Urochloa brizantha (CRUZ et al., 2011; PEZZOPANE et al., 2012a, 2012b; TONATO et al., 2010). Furthermore, the use and improvement of geographic information systems (GIS) have increased the application of geoprocessing techniques, which allow a rapid delimitation of potential productive areas for crops, with reliable results (SILVA et al., 2009). GIS are used to collect, analyze, organize and layer spatial data describing the physical and logical properties of the geographic world (BURROUGH; MCDONNELL, 1998).

The determination of areas suitable for the production of Tanzania guineagrass pastures in the state of Ceará, would allow a reduction in costs, time and risks for farmers and would contribute to improving animal production systems sustainability in semiarid areas. Also, the use of irrigation to overcome water limitation for pasture production, may maximize the use of pasture throughout the year.

This study aimed to define areas suitable, and the irrigation water requirement for, cultivation of Tanzania guineagrass in the state of Ceará.

\section{MATERIAL AND METHODS}

Tanzania guineagrass forage production was estimated by a mathematical model, initially proposed by Pezzopane et al. (2012b) for local conditions of the state of Sao Paulo, and later adapted for broader Brazilian conditions by the use of data from Sao Carlos, SP, Piracicaba, SP, Juiz de Fora, MG and Sobral, CE for parameterization. Detailed data on herbage accumulation rate from São Carlos, SP, and Piracicaba, SP can be found in Pezzopane et al. (2012b). Data from Juiz de Fora, MG, and Sobral, CE, were obtained from rainfed and irrigated plots between 2009 and 2012. Plots were annually fertilized with $360 \mathrm{~kg} \mathrm{ha}^{-1}$ of nitrogen and were cut every 30 days. Briefly, parameters of simple linear regression between herbage accumulation rates of irrigated Tanzania guineagrass and crop actual evapotranspiration (ETa) from 54 cycles of growth were estimated by the least square means method (PEZZOPANE et al., 2012b). Herbage accumulation rate was estimated based on ETa (PEZZOPANE et al., 2012b).

The accumulation rate in dry matter (ARDM) per month was estimated from equation (1). Climate data from a grid of 298 locations in Ceará and in surrounding regions was used to enable a statewide spatial analysis.

$$
\operatorname{ARDM}\left(\mathrm{kg} \mathrm{DM} \mathrm{ha}^{-1} \mathrm{day}^{-1}\right)=34.73 . \mathrm{ETa}-21.58
$$

In this study, observed and estimated data of temperature and rainfall from a spreadsheet called "BHGEOclima" (Climatological Water Balance for Georeferencing in the Northeast of Brazil) were used, referring to the average of the period 19611990. This spreadsheet allows estimating both the normal climatological water balance and the crop climatological water balance. The observed values of rainfall belong to the database of the Department of Atmospheric Sciences of the Federal University of Campina Grande (Figure 1).

For the other locations, the maximum and minimum air temperature average was estimated using the equation proposed by Alvarez et al. (2013), as follows:

$T i=a_{0}+a_{1} \varphi+a_{2} \lambda+a_{3} h+a_{4} \varphi \lambda+a_{5} \varphi h+a_{6} \lambda h+a_{7} \varphi^{2}+a_{8} \lambda^{2}+a_{9} h^{2}$

where $\mathrm{Ti}$ is the maximum or minimum, monthly $(i=1,2, \ldots, 12)$ or yearly $(i=13)$ temperature in degrees; $\varphi$ is the latitude in decimal degrees (positive values in the northern hemisphere and negative values in the southern hemisphere); $\lambda$ is the longitude in decimal degrees (negative values); $h$ is the altitude (in meters); and $\mathrm{a}_{0}$ to $\mathrm{a}_{9}$ are the coefficients of multivariate regression equation. 


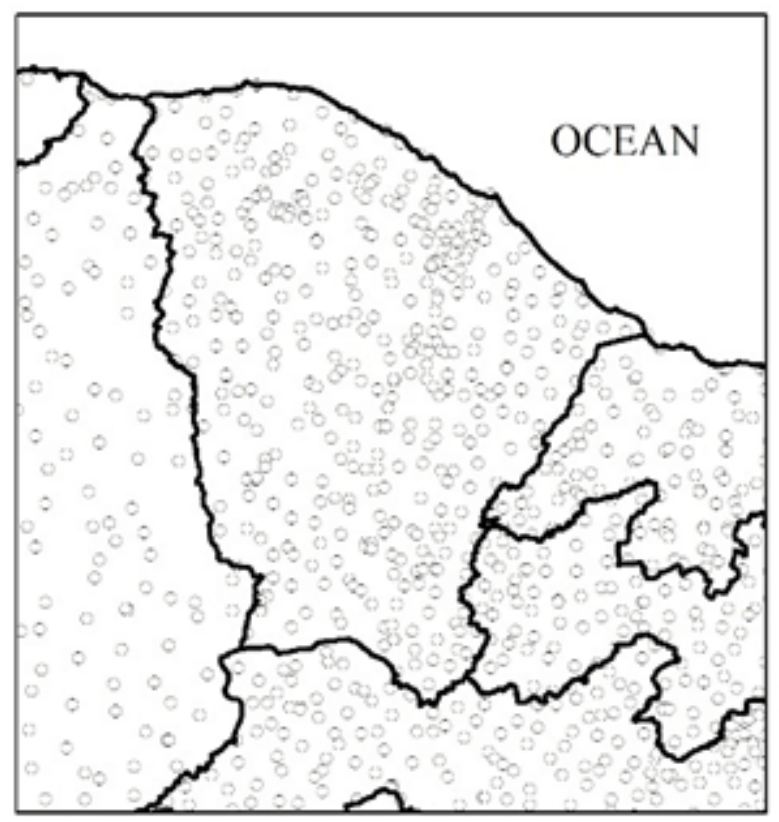

○ Pluviometric station

Weather station

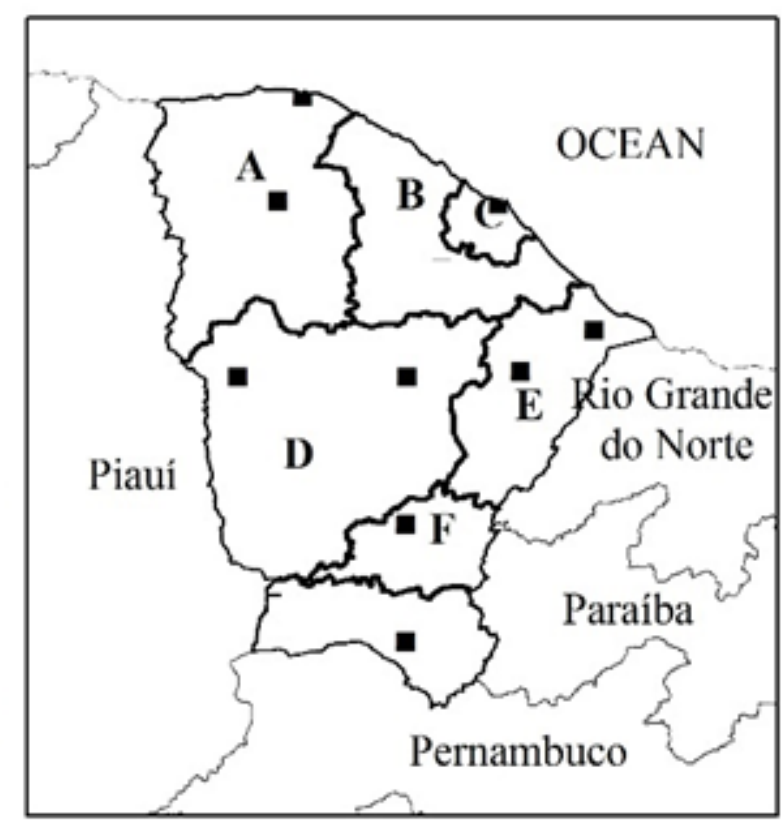

Mesoregions
A - Noroeste
E - Jaguaribe
B - Norte
C - Metropolitana
F - Centro Sul
D - Sertões

Figure 1. Location of pluviometric stations and weather stations used in the mapping and definition of the agricultural calendar for Tanzania guineagrass cultivation in Ceará.

The ETa was estimated through crop climatological water balance (THORNTHWAITE; MATHER, 1955) using the 'BHGEOclima' spreadsheet and considering four soil water holding capacities $(20,40,60$, and $100 \mathrm{~mm})$. These values were adopted to contemplate the various soil types and the variations in the growth of the root system of the crop. These four water holding capacity values characterized shallow soils $(\mathrm{AWC}=20 \mathrm{~mm})$, sandy soils (AWC $=40 \mathrm{~mm}$ ), medium-textured soils (AWC $=60 \mathrm{~mm})$ and clay soils $(\mathrm{AWC}=100 \mathrm{~mm})$.

$$
\text { In the spreadsheet, potencial }
$$
evapotranspiration data (PET) were calculated according to the method of Thornthwaite (1948), adjusted by Camargo et al. (1999) to avoid underestimation during the dry season. With PET data, the crop evapotranspiration (ETc) was estimated with a 0.6 average monthly culture coefficient (kc) (RODRIGUES et al., 2011), as follows:

$$
\mathrm{ETc}=\mathrm{PET} \times \mathrm{kc}
$$

Through crop climatological water balance, the irrigation requirement for water replacement throughout the year was also estimated for soils with water holding capacity values of $20,40,60$ and $100 \mathrm{~mm}$.

In addition to monthly estimates, ARDM values were also calculated on a daily scale from a set of climatological data from Sobral, Acaraú, Fortaleza, Crateús, Quixeramobim, Morada Nova, Jaguaruana, Iguatu and Juazeiro, which are well distributed throughout the territory of Ceará and include most of the state's economic mesoregions (Figure 1). These data were obtained from the Meteorological Database for Teaching and Research of the Brazilian Meteorology National Institute (http://www.inmet.gov.br/portal/index.php?

$\mathrm{r}=\mathrm{bdmep} / \mathrm{bdmep}$ ), with the data series over 40 years old. With these daily ARDM data, the relative frequency of occurrence of monthly productivity of Tanzania guineagrass above $2,750 \mathrm{~kg} \mathrm{DM} \mathrm{ha}^{-1}$ month $^{-1}$ was obtained (equivalent to an annual productivity of 33,000 kg MS ha ${ }^{-1}$ year $^{-1}$ ) (JANK et al., 1997) for the definition of crop growing seasons. The $70 \%$ probability of occurrence of monthly productivity values above $2,750 \mathrm{~kg} \mathrm{DM} \mathrm{ha}{ }^{-1} \mathrm{month}^{-1}$ was assumed in establishing the agricultural calendar of the main mesoregions of Ceará.

The annual and monthly herbage production of Tanzania guineagrass was mapped for the state 
through ArcGIS software version 9.3 using the Spatial Analyst extension and the Ordinary Kriging method, according to procedures described by Silva et al. (2009).

\section{RESULTS AND DISCUSSION}

Annual Tanzania guineagrass productivity in Ceará, predicted by an agrometeorological model, was between 20,000-30,000 kg DM ha ${ }^{-1}$ year ${ }^{-1}$. These estimates are close to the production values obtained in experiments with this grass in other states (BARBERO et al., 2014; CANTO et al., 2013; LEMOS et al., 2014) and also under irrigated conditions in the state of Ceará (CUTRIM JÚNIOR et al., 2011; SILVA et al., 2007). As the soil water holding capacity used in the simulations increased, the area with a climatic potential for production of Tanzania guineagrass also increased (Figure 2).

In the eastern portion of the Sertões region, an increase of around $60 \%$ in the area with climatic potential to produce more than $25,000 \mathrm{~kg}$ DM ha ${ }^{-1}$ year $^{-1}$ was estimated when compared with the area of high forage production potential estimated considering $20 \mathrm{~mm}$ of soil water holding capacity. However, most of the state's soils present a $20-40 \mathrm{~mm}$ water holding capacity. In the Sertões region, there is a greater amount of dystrophic red-yellow podzolic soils, which have good fertility attributes, but that are limited by problems related to soil physics. For this reason, the cultivation of Tanzania guineagrass in this area is recommended for soils with a higher soil water holding capacity, particularly for the municipalities of Acopiara, Piquet Carneiro, Senador Pompeu, Irapuã Pinheiro, parts of Mombaça and Quixeramobim, Quixadá, Ibaretama and part of Choró. An increase in forage production was also observed in the Jaguaribe Valley region, which traditionally has a high potential for milk and fruit production with irrigation, for there are predominantly deeper Cambisols. The municipalities present in this region are Quixeré and Tabuleiro do Norte, which is part of Limoeiro do Norte.

Figure 3 illustrates the predicted monthly production of Tanzania grass. The highest production in the state occurs in March and April. It is possible to observed, particularly during the rainy season (January-June), that the state's productive potential varies according to the economic mesoregion, which presents different climatic conditions, with a higher rainfall in the coastal strip of the Northwest, North, Metropolitan, South Central and Southern regions.
From June, in part of the region of Sertões and Southern Ceará, the simulated yields are less than $1,250 \mathrm{~kg} \mathrm{DM} \mathrm{ha}{ }^{-1}$ month $^{-1}$, and this pattern repeats across the state between August and December, Consequently, there are no differences among mesoregions during the dry season (Figure 3). The literature presents dry mass production values of forage ranging from 2,000-5,000 kg DM ha ${ }^{-1} \mathrm{month}^{-1}$ (CUTRIM JÚNIOR et al., 2011; SILVA et al., 2007) in the state of Ceará. However, these values were obtained using irrigation. Under rainfed conditions, the low expected yields in the state are mainly due to the effect of the Atlantic tropical air mass that dominates the equatorial continental air mass, the latter being responsible for rainfalls (REBOITA et al., 2012).

Figure 4 shows the delimitation of the agricultural calendar for the cultivation of Tanzania grass under dry-farm conditions in municipalities that are representatives of mesoregions of Ceará that have a weather station.

This analysis evidences the suitability of Tanzania guineagrass production in the municipalities of Sobral and Acaraú from MarchMay in the northern mesoregion (Figure 4B and 4C). In the Sertão region (Figure $4 \mathrm{E}$ and $4 \mathrm{~F}$ ), represented by Crateús and Quixeramobim, only 2 months are favorable, but a difference between the Inhamuns Sertão (Crateús) and the Central Sertão (Quixeramobim) can be observed, regarding the most favorable periods: the first, earlier (March and April) and the second, later (April and May). Such a difference is attributed to rainfall in regions for which different timelines occur. The valley of Jaguaribe is suitable for Tanzania guineagrass production in rainfed conditions for 3 months: in Morada Nova, February, March and April; and in Jaguaruana, March, April and May. For the southern region of Iguatu, a city located in the south-central region, March-May showed a potential to produce Tanzania guineagrass pastures (Figure 4I). Similarly, but starting in February, the city of Juazeiro do Norte, in south Ceará, produced Tanzania guineagrass for 3 months.

Considering these results, it was possible to observe that the cultivation of Tanzania grass in rainfed conditions becomes a high-risk activity, limited to a few months during the rainiest months. The irregularity in the distribution of rainfall encourages a search for alternatives, such as irrigation, to enable the use of this grass in the state of Ceará. Thus, in Figures 5, 6, 7 and 8, the need for a monthly water replacement is demonstrated for different soil water holding capacities. 

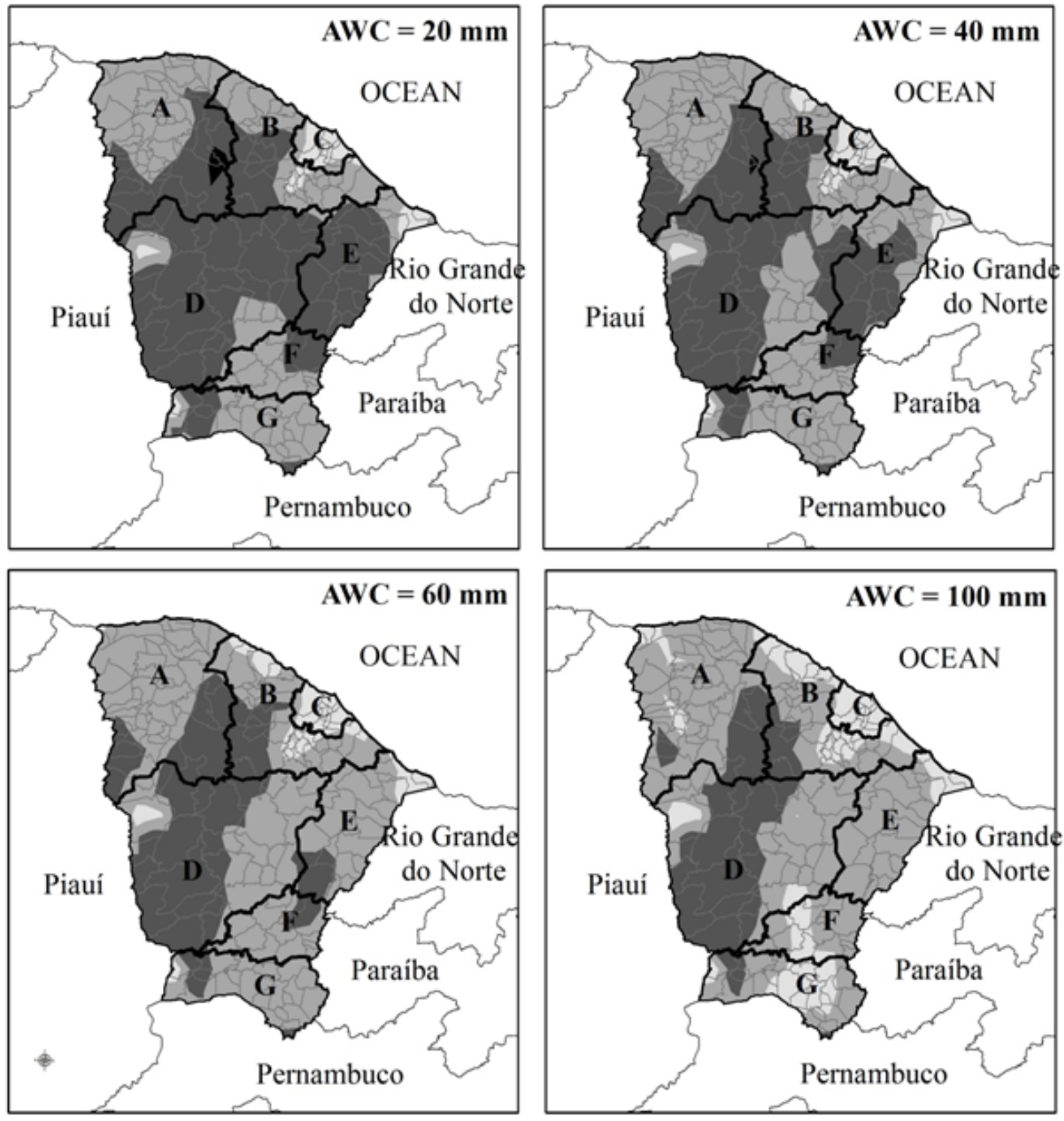

Annual production (kg DM / ha / year)

Mesoregions

$<20,000$

$20,000-25,000$

$25,000-30,000$

$>30,000$
A - Noroeste
E - Jaguaribe
B - Norte
F - Centro Sul
C - Metropolitana G - Sul
D - Sertões

Figure 2. Annual production of Tanzania guineagrass $\left(\mathrm{kg} \mathrm{DM} \mathrm{ha}^{-1} \mathrm{year}^{-1}\right)$ grown in soils with various soil water holding capacities $(20,40,60$ and $100 \mathrm{~mm})$ in the state of Ceará, simulated with agrometeorological models. 

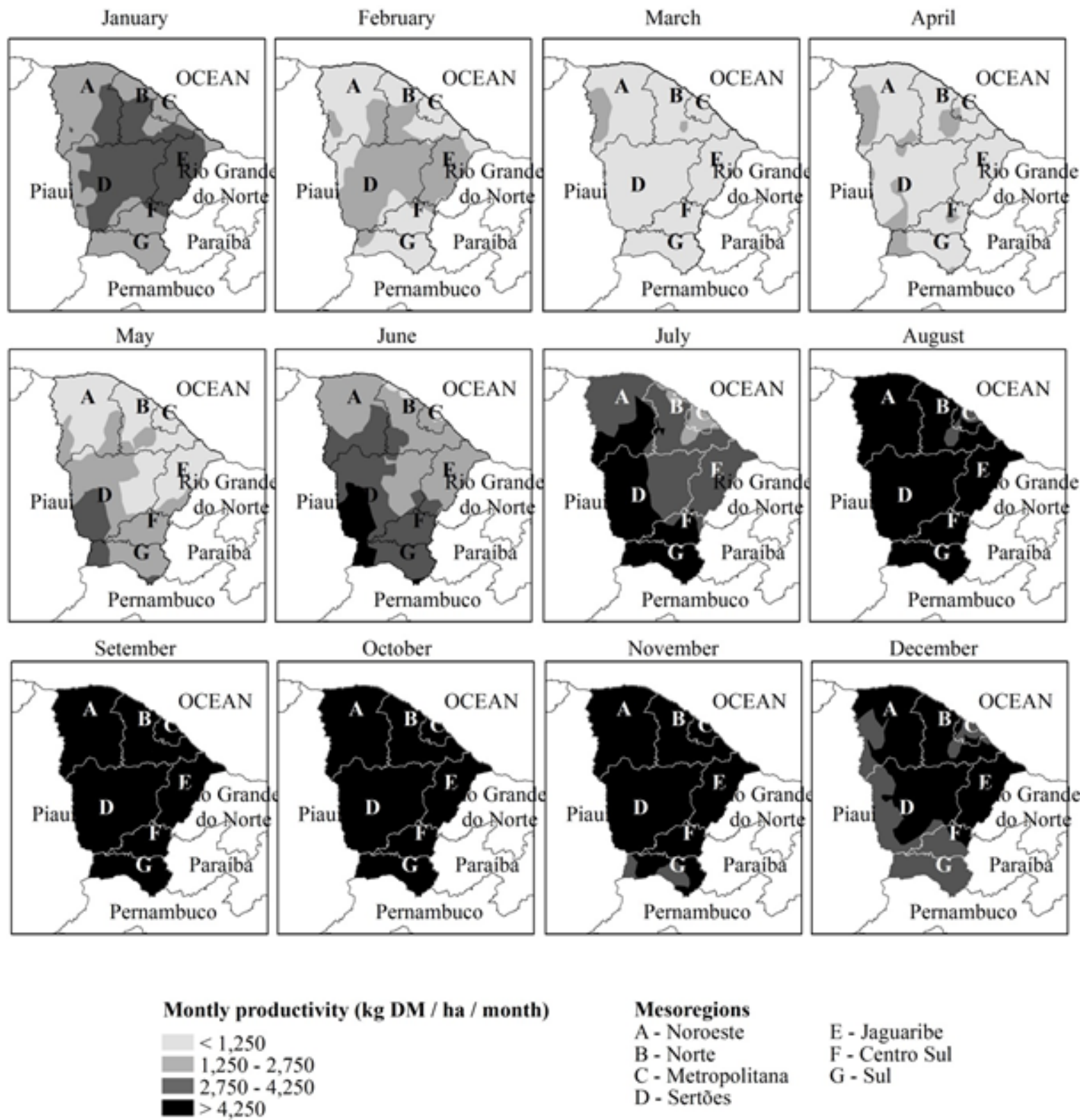

$\begin{array}{ll}\text { Mesoregions } & \\ \text { A- Noroeste } & \text { E- Jaguaribe } \\ \text { B- Norte } & \text { F - Centro Sul } \\ \text { C- Metropolitana } & \text { G - Sul } \\ \text { D- Sertóes } & \end{array}$

Figure 3. Monthly productivity of Tanzania guineagrass $\left(\mathrm{kg} \mathrm{DM} \mathrm{ha}^{-1} \mathrm{month}^{-1}\right)$ according to the soil (100 $\mathrm{mm}$ water holding capacity) and climate conditions in the respective mesoregions of the state of Ceará. (A) Noroeste; (B) Norte; (C) Metropolitana; (D) Sertões; (E) Jaguaribe; (F) Centro Sul; (G) Sul.

The need for water replacement with $20 \mathrm{~mm}$ soil water holding capacity is illustrated in Figure 5. In January and February, when the distribution of rainfall in the state is still uneven, most of the Northwest, North, Sertão and part of Jaguaribe regions require a $100-150 \mathrm{~mm}$ replacement in January and a 50-100 mm replacement in February. In March and April, the replacement may be $0-50 \mathrm{~mm}$ in the entire state. From May, the Sertão and the South region require a $50-100 \mathrm{~mm}$ water supplementation. In June, a greater range that spans the Northwest, Sertão and South needs 100-150 mm. From July, the need for $150-200 \mathrm{~mm}$ water replacement occurs in the northwest and tends to spread throughout the region as the months of the dry season advance. From November, there is a reduction in water requirement from the South, because the rains start earlier in this region under the influence of the Atlantic tropical mass. 


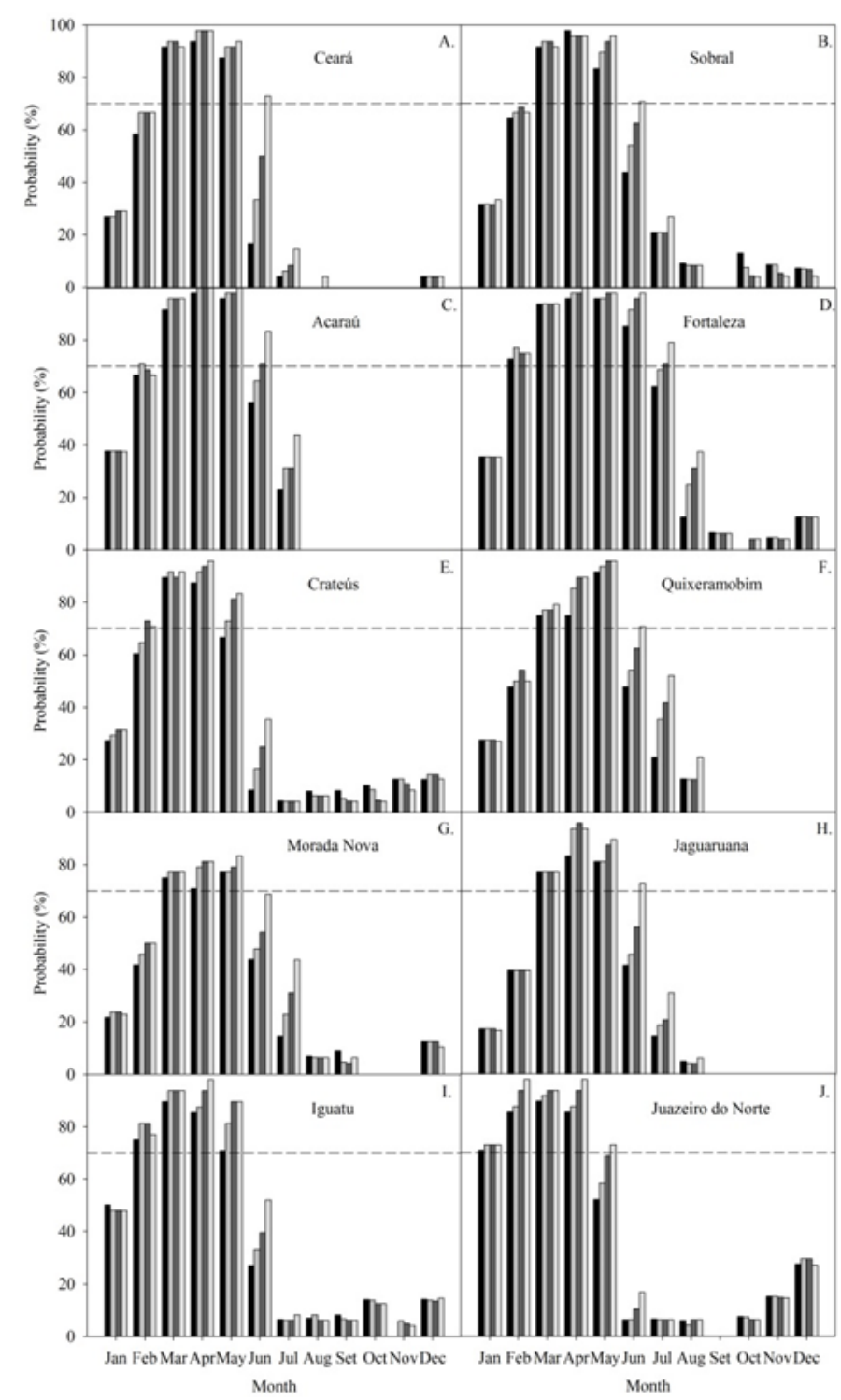

Figure 4. Agricultural calendar for Tanzania guineagrass cultivation in Ceará based on at least $70 \%$ probability of occurrence of productivity values above $2,750 \mathrm{~kg} \mathrm{DM} \mathrm{ha}^{-1} \mathrm{month}^{-1}$.

The need for water replacement with a $40 \mathrm{~mm}$ AWC is illustrated in Figure 6. The greatest differences in relation to $20 \mathrm{~mm}$ AWC are observed in May, June and July. In the South, in May (Figure 6), less area needs a 50-100 mm replacement when compared with the same region in Figure 5. In June (Figure 6), there are reductions in part of the North region, Metropolitan and Jaguaribe areas that need a water replacement of 50-100 mm compared to this same month with a $20 \mathrm{~mm}$ AWC. Finally, in
July, which has $40 \mathrm{~mm} \mathrm{AWC} \mathrm{in} \mathrm{the} \mathrm{Northwest}$ region, fewer areas requiring a maximum water replacement are observed. It can be seen that a $20 \mathrm{~mm}$ increase in water absorption capacity can increase water use efficiency for the production of Tanzania grass in parts of the South, North, Northwest, Metropolitan and Jaguaribe regions from May-July. However, for most months, particularly in the Sertão region, the increase in AWC had no effect on reducing the need for water replacement. 

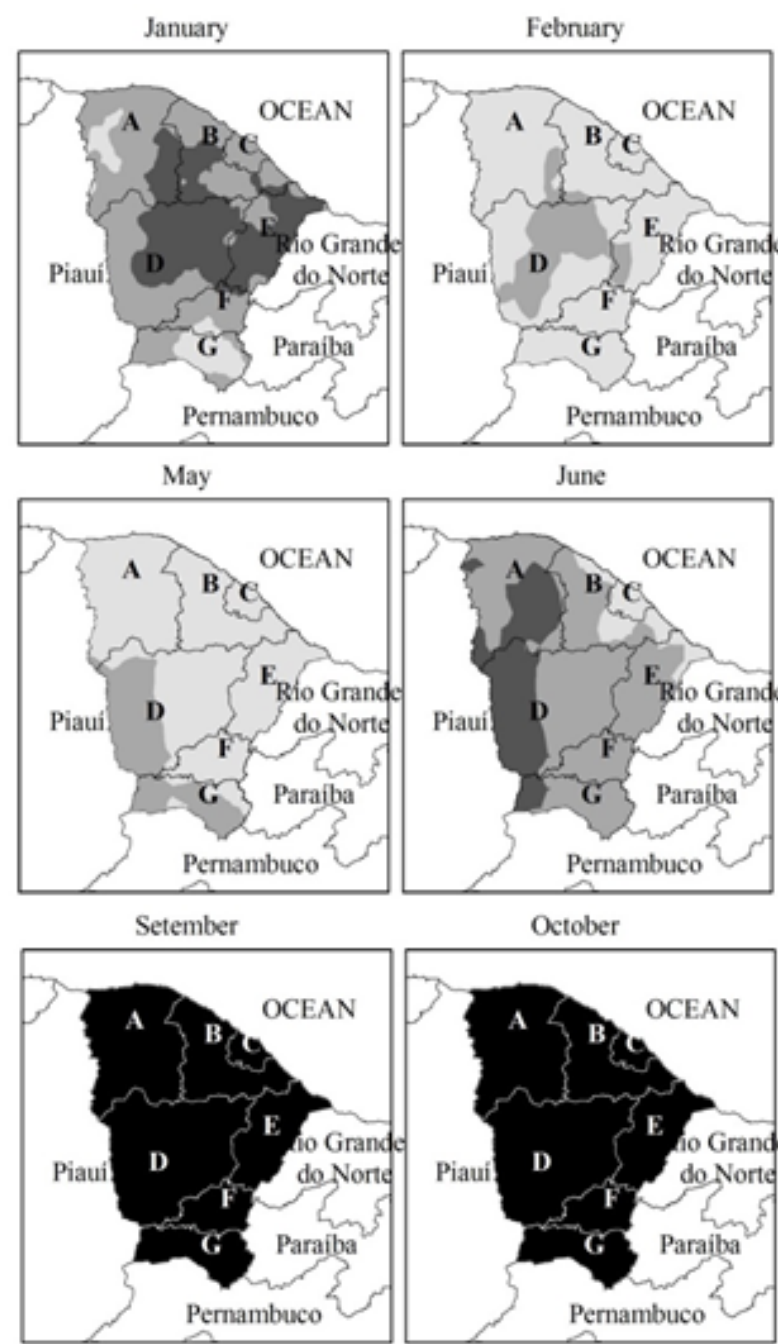

June

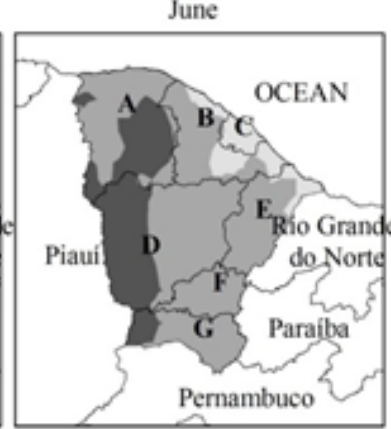

October

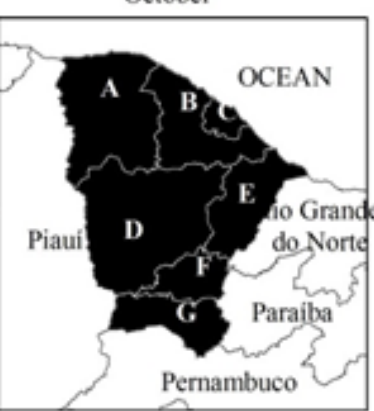

Pernambuco

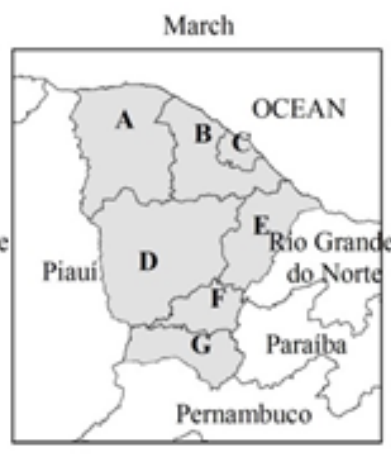

July

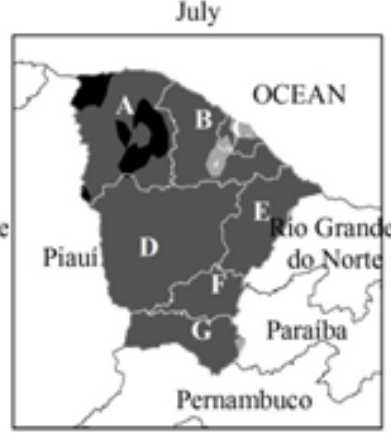

November

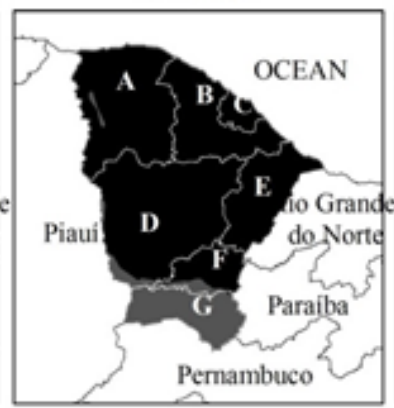

Mesoregions

A - Noroeste

B - Norte

C - Metropolitana

D - Sertoes

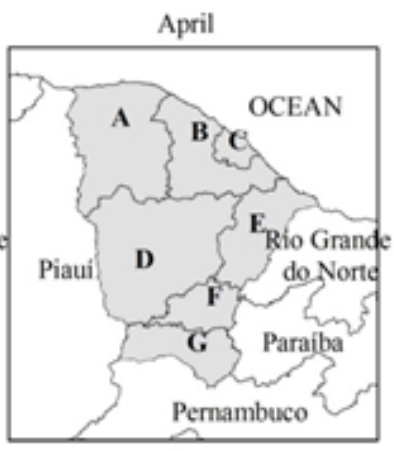

August

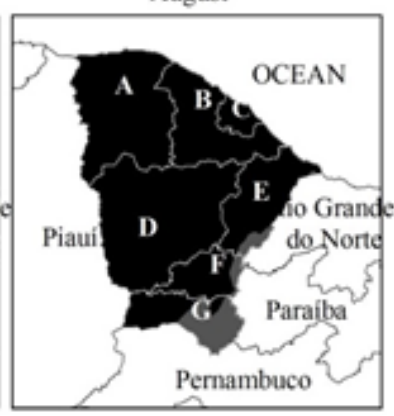

December

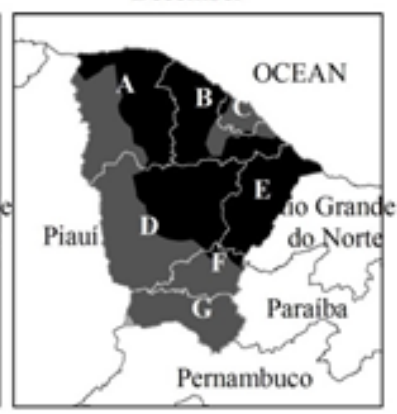

E - Jaguaribe

F - Centro Sul

G - Sul

Figure 5. Monthly water replacement need $\left(\mathrm{mm} \mathrm{month}^{-1}\right)$ for Tanzania guineagrass cultivation with a 20 -mm soil water holding capacity throughout the year in the respective mesoregions of the state of Ceará. (A) Noroeste; (B) Norte; (C) Metropolitana; (D) Sertões; (E) Jaguaribe; (F) Centro Sul; (G) Sul.

Figure 7 displays the need for water replacement for a $60 \mathrm{~mm}$ AWC. A reduction in water requirement is observed in the eastern regions of Sertão, part of the northern region, metropolitan area and Jaguaribe in May compared to the same regions with a $40 \mathrm{~mm}$ AWC in the same month. In
July, a $100-150 \mathrm{~mm}$ reduction in water replacement need was observed in part of the North, Metropolitan, Jaguaribe, South Central and Southern regions. In August, it is possible to observe fewer areas with a maximum need for water replacement, particularly in part of the metropolitan area, Jaguaribe and South. 


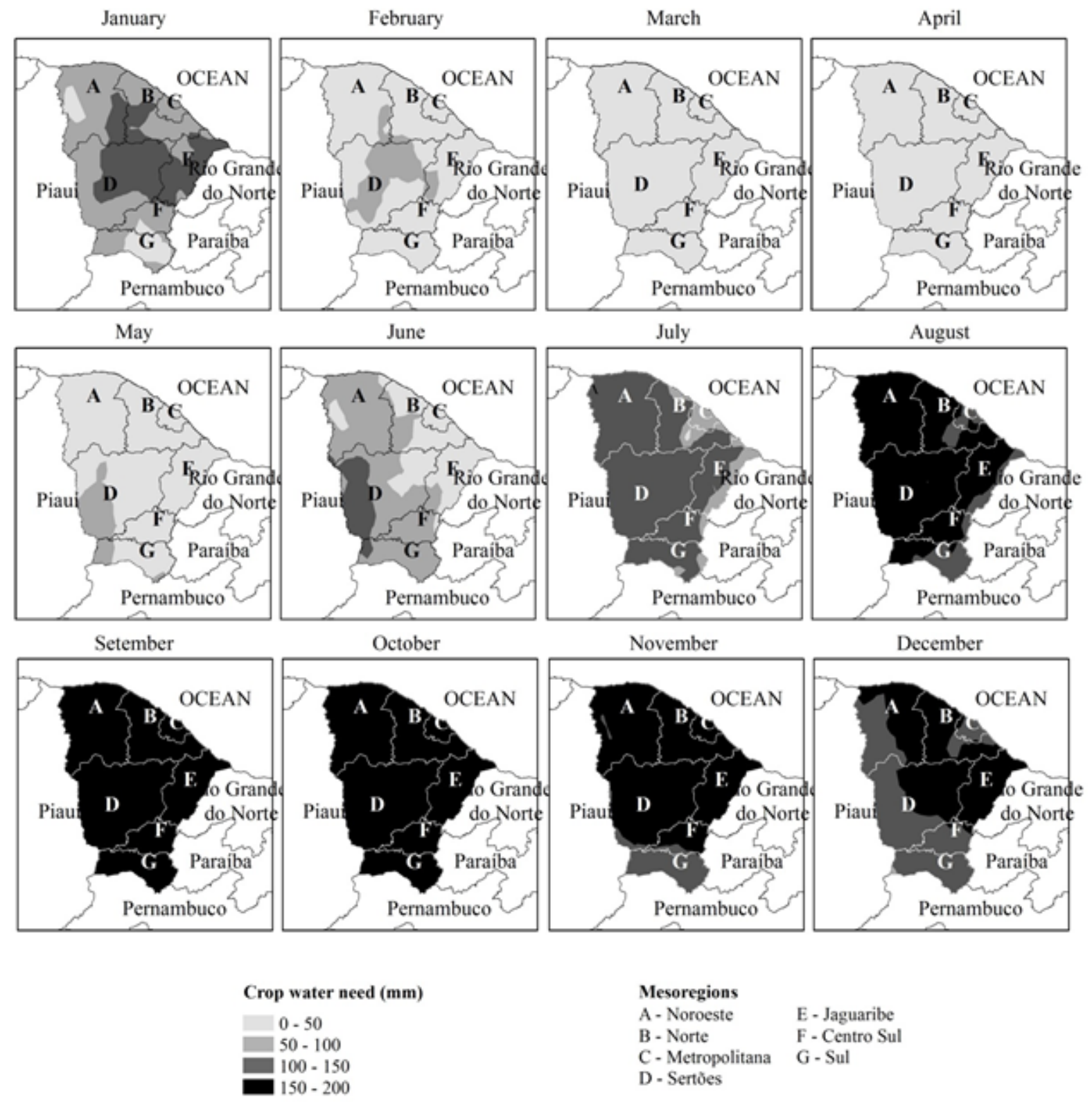

Figure 6. Monthly water replacement need $\left(\mathrm{mm} \mathrm{month}^{-1}\right)$ for Tanzania guineagrass cultivation with a 40 -mm water storage capacity $(\mathrm{AWC}=40 \mathrm{~mm})$ throughout the year in the respective mesoregions of the state of Ceará. (A) Noroeste; (B) Norte; (C) Metropolitana; (D) Sertões; (E) Jaguaribe; (F) Centro Sul; (G) Sul.

The need for water replacement with a $100 \mathrm{~mm}$ AWC is illustrated in Figure 8. It is noticed that there is a reduced need for water replacement in relation to a $60 \mathrm{~mm}$ AWC, particularly between June and August, for parts of Northwest, North, Metropolitan, Jaguaribe Valley and east of the Sertão regions. In June, in these regions, the need for water replacement was between $0-50 \mathrm{~mm}$. As the dry season approached, the water requirement gradually increased to $50-100 \mathrm{~mm}$ in July and to $100-150 \mathrm{~mm}$ in August, where, while in this same period, water requirement was $40 \mathrm{~mm}$, the water requirement was already maximum (150-200 $\mathrm{mm})$. 


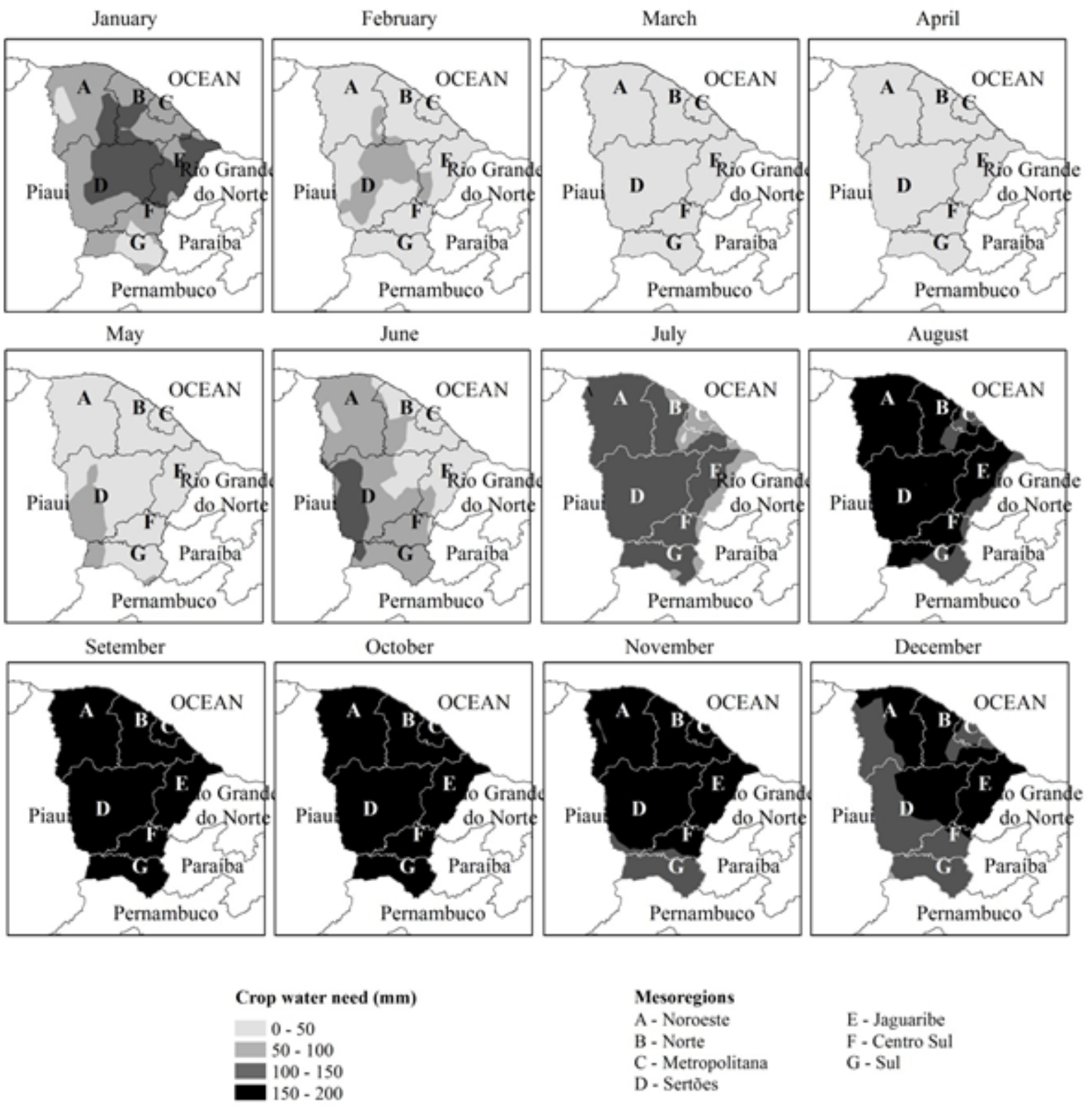

Figure 7. Monthly water replacement need $\left(\mathrm{mm} \mathrm{month}^{-1}\right)$ for Tanzania guineagrass cultivation with a 60 -mm water storage capacity $(\mathrm{AWC}=60 \mathrm{~mm})$ throughout the year in the respective mesoregions of the state of Ceará. (A) Noroeste; (B) Norte; (C) Metropolitana; (D) Sertões; (E) Jaguaribe; (F) Centro Sul; (G) Sul.

Interestingly, during the dry season, the need for water replacement was in the same range $(150-200 \mathrm{~mm})$ for all simulated AWCs. This result is probably associated with climate and ETc (PEREIRA et al., 2002). Considering the dry scenarios that have frequently occurred in Ceará in the past 4 years, technologies that increase water use efficiency should be recommended to avoid waste and economic and environmental damage.

In order to increase water use efficiency in Tanzania guineagrass pastures, the use of an irrigation depth according to the soil water holding capacity is recommended, because very high irrigation depths increase water and nutrient losses through percolation (SORIA et al., 2003). Another strategy to increase water use efficiency is to use nitrogen fertilizer. Silva et al. (2007) obtained a higher efficiency for the production of irrigated Tanzania grass in the state of Ceará by applying $600 \mathrm{~kg}$ of nitrogen per hectare/year, with a monthly irrigation depth of around $200 \mathrm{~mm}$. 

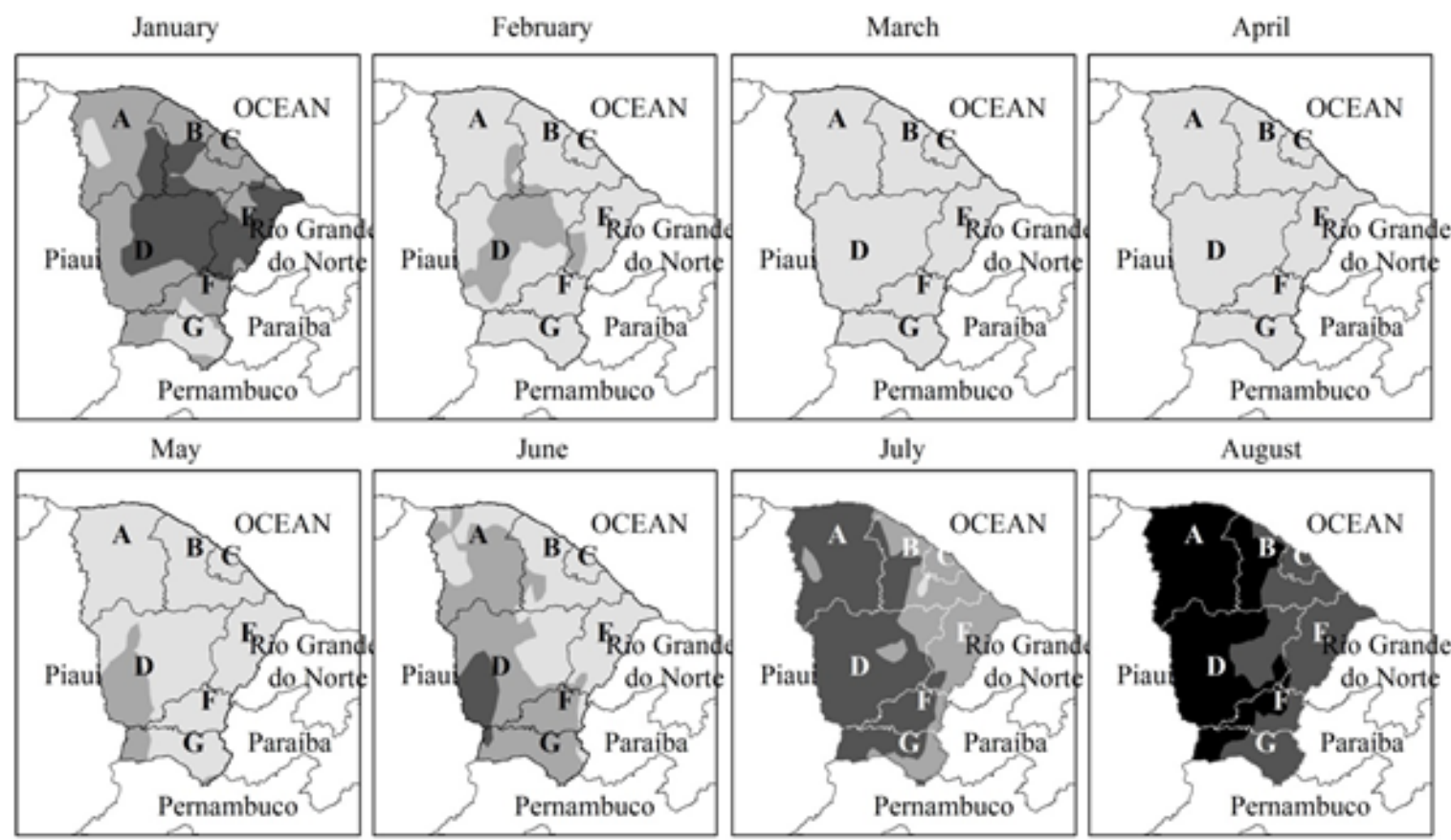

August
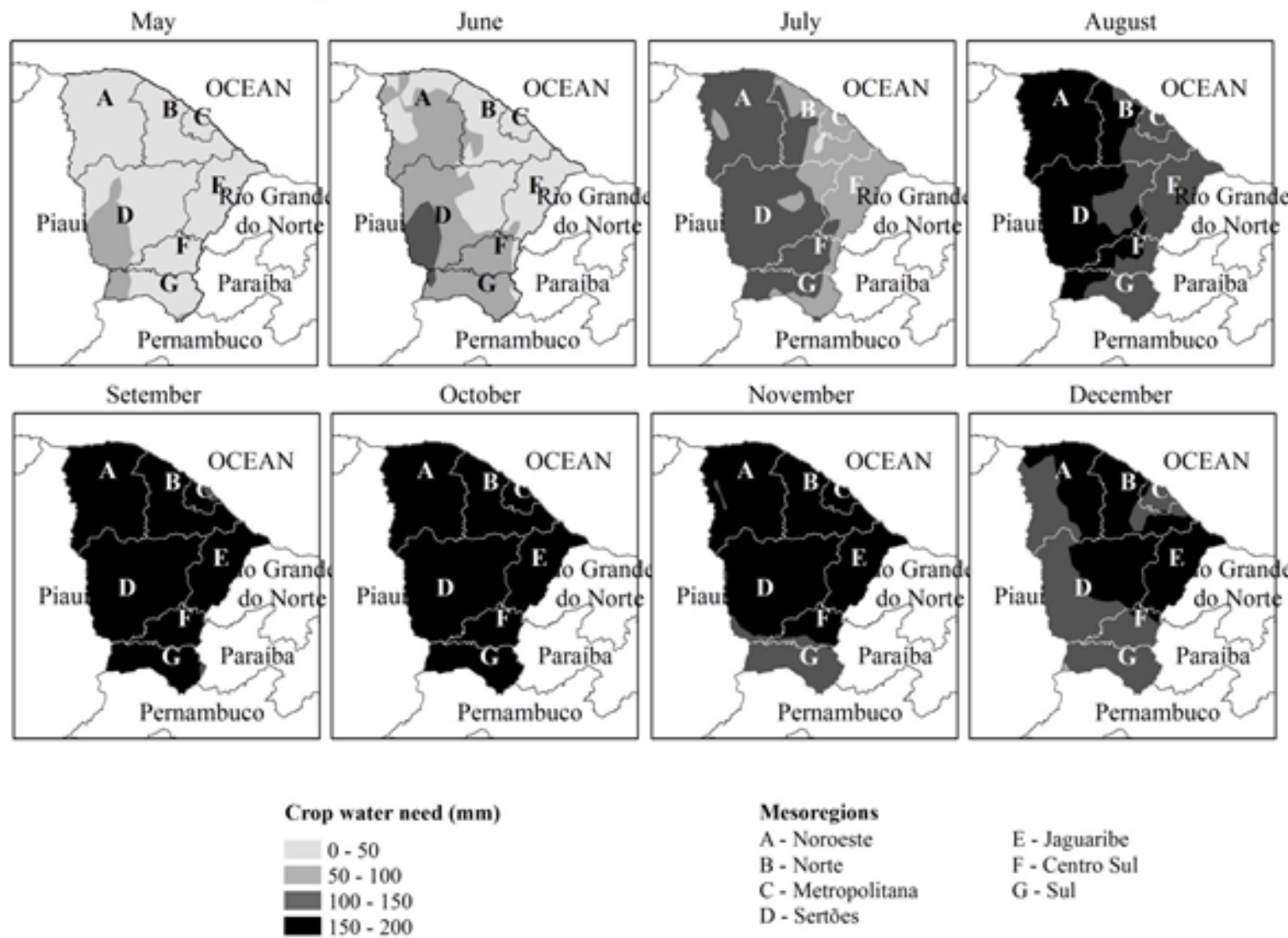

Figure 8. Monthly water replacement need $\left(\mathrm{mm} \mathrm{month}^{-1}\right)$ for Tanzania guineagrass cultivation with a 100 -mm water storage capacity (AWC $=100 \mathrm{~mm}$ ) throughout the year in the respective mesoregions of the state of Ceará. (A) Noroeste; (B) Norte; (C) Metropolitana; (D) Sertões; (E) Jaguaribe; (F) Centro Sul; (G) Sul.

\section{CONCLUSIONS}

The state of Ceará is suitable for the production of Tanzania guineagrass under rainfed conditions only for 4 months, predominantly from February-May because weather conditions do not favor the development of grass in the remaining months. Water replacement through irrigation is an alternative that should be considered to maintain production models based on Tanzania guineagrass pastures throughout the year in the state of Ceará.

\section{REFERENCES}

ALVAREZ, C. A. et al. Modeling monthly mean air temperature for Brazil. Theoretical and Applied
Climatology, Vienna, v. 113, n. 3, p. 407-427, 2013.

BARBERO, R. P. et al. Características produtivas e morfológicas do capim Tanzânia em diferentes intensidades de pastejo. Semina: ciências agrárias, Londrina, v. 35, n. 1, p. 427-436, 2014.

BURROUGH, P. A.; MCDONNEL, R.A. Principle of geographical information systems. 2. ed. New York: Oxford University Press, 1998. 333 p.

CAMARGO, A. P. et al. Ajuste da equação de Thornthwaite para estimar a evapotranspiração potencial em climas áridos e superúmidos, com base na amplitude térmica diária. Revista Brasileira de Agrometeorologia. Santa Maria, v. 7, n. 2, p. 251-257, 1999. 
CANTO, M. W. et al. Características do pasto e eficiência agronômica de nitrogênio em capim-Tanzânia sob pastejo contínuo, adubado com doses de nitrogênio. Ciência Rural. Santa Maria, v. 43 , n. 4, p. 682-688, 2013

CRUZ, P. G. et al. Modelos empíricos para estimar o acúmulo de matéria seca de capim-marandu com variáveis agrometeorológica. Pesquisa Agropecuária Brasileira. Brasília, v. 46, n. 7, p. 675-681, 2011.

CUTRIM JUNIOR, J. A. A. et al. Fluxo de biomassa em capim-Tanzânia sob três frequências de desfolhação e dois resíduos pós-pastejo. Revista Brasileira Saúde e Produção Animal. Salvador, v. 11, n. 3, p. 618-629, 2010.

CUTRIM JÚNIOR, J. A. A. et al. Características estruturais do dossel de capim-Tanzânia submetido a três frequências de desfolhação e dois resíduos pós-pastejo. Revista Brasileira de Zootecnia, Viçosa, v. 40, n. 3, p. 489-497, 2011.

JANK, L. et al. Catalog of the characterization and evaluation of the Panicum maximum germplasm: morphological description and agronomical performance. 1. ed. Campo Grande: EMBRAPA Gado de Corte, 1997. 53 p. (Documento Embrapa Gado de Corte, 68).

JANK, L. et al. Panicum maximum Jacq. In: FONSECA, D. M.; MARTUSCELlO, J. A (Eds.). Plantas forrageiras. Viçosa: editora UFV, 2010. v. 1, cap. 5, p. 166-196.

LEMOS, N. L. S. et al. Tanzania grass structure grazed by goats managed with different residual leaf area index under intermittent stocking. Bioscience Journal, Uberlândia, v. 30, n. 6, p. 1811-1818, 2014.

PEREIRA, A. R. et al. Agrometeorologia: Fundamentos e Aplicações Práticas. 1. ed. Guaíba, RS: Livraria e Editora Agropecuária, 2002. 478 p.

PEZZOPANE, J. R. M. et al. Zoneamento de aptidão climática para os capins Marandu e Tanzânia na região Sudeste do Brasil. 1. ed. São Carlos: Embrapa Pecuária Sudeste, 2012a. 27 p. (Documento Embrapa Pecuária Sudeste, 108).

PEZZOPANE, J. R. M. et al. Dry matter production of Tanzania grass as a function of agrometeorological variables. Pesquisa Agropecuária Brasileira, Brasília, v. 47, n. 4, p. 471-477, 2012b.

POMPEU, R. C. F. F. et al. Componentes da biomassa pré-pastejo e pós-pastejo de capim-Tanzânia sob lotação rotativa com quatro níveis de suplementação concentrada. Revista Brasileira de Zootecnia, Viçosa, v. 37, n. 3, p. 383-393, 2008

POMPEU, R. C. F. F. et al. Comportamento de ovinos em capim-Tanzânia sob lotação rotativa com quatro níveis de suplementação concentrada. Revista Brasileira de Zootecnia, Viçosa, v. 38, n. 2, p. 374-383, 2009a.

POMPEU, R. C. F. F. et al. Desempenho de ovinos em capim-Tanzânia sob lotação rotativa com quatro proporções de suplementação concentrada. Arquivo Brasileiro de Medicina Veterinária e Zootecnia, Belo Horizonte, v. 61, n. 5, p. 1104-1111, 2009 b.

REBOITA, M. S. et al. Entendendo o tempo e o clima na América do Sul. Terrae Didática, Campinas, v. 8, n. 1, p. 34-50, 2012.

RODRIGUES, B. H. N. et al. Evapotranspiração e coeficiente de cultura do capim-Tanzânia. 1. ed. Teresina: Embrapa Meio-Norte, 2011. 23 p. (Documento Embrapa Meio-Norte, 98).

SILVA, R. G. et al. Eficiência no uso da água e do nitrogênio na produção do capim Tanzânia em sistema de pastejo rotacionado de ovinos. Engenharia Rural, Piracicaba, v. 18, n. 5, p. 69-75, 2007.

SILVA, T. G. F. et al. Potencial pedoclimático do Estado da Bahia para o cultivo da atemóia. Revista Brasileira de Engenharia Agrícola e Ambiental, Campina Grande, v. 13, n. 5, p. 566-574, 2009.

SORIA, L. G. T. et al. Resposta do capim-Tanzânia a aplicação do nitrogênio e de lâminas de irrigação. I: Produção de forragem. Revista Brasileira de Engenharia Agrícola e Ambiental, Campina Grande, v. 7, n. 3, p. 430-436, 2003.

THORNTHWAITE, C. W. An approach toward a rational classification of climate. Geographical Review, v. 38, n. 1, p. 55-94, 1948.

THORNTHWAITE, C. W.; MATHER, J. R. The water balance: Publications in Climatology. New Jersey: Drexel Institute of Technology, 1955. 104 p.

TONATO, F. et al. Desenvolvimento de modelos preditores de acúmulo de forragem em pastagens tropicais. Pesquisa Agropecuária Brasileira, Brasília, v. 45, n. 5, p. 522-529, 2010.

VALENTE, B. S. M. et al. Composição químico-bromatológica, digestibilidade e degradação in situ da dieta de ovinos em capim-Tanzânia sob três frequências de desfolhação. Revista Brasileira de Zootecnia, Viçosa, v. 39, n. 1, p. 113-120, 2010 